\title{
Nidification of Polybia platycephala and Polistes versicolor (Hymenoptera: Vespidae) on Plants of Musa spp. in Minas Gerais State, Brazil
}

by

\author{
F.A. Rodríguez ${ }^{1}$, L.C. Barros ${ }^{2}$, P. Caroline ${ }^{2}$, M.M. Souza ${ }^{1}$, J.E. Serrão ${ }^{3}$ \\ $\&$ J.C. Zanuncio ${ }^{1 *}$
}

\begin{abstract}
Social wasps are natural enemies of caterpillars and, therefore, they have potential to control insect pests in various crops. Three colonies of Polybia platycephala (Richards) and one of Polistes versicolor (Olivier) (Hymenoptera: Vespidae) were found on plants of banana (Musa spp.) in Minas Gerais State, Brazil. These colonies were at $3.50 \mathrm{~m}$ high, under the leaves, which provide shelter from environmental stress.

Key Words: Banana, biological control, nest, pest, social wasps.

\section{INTRODUCTION}

Social wasps have many functions in ecosystems as pollinators, predators of insects, bioindicators and nutrient cycling (Souza et al. 2010). Social wasps are agents of biological control (Prezoto \& Gobbi 2005; Picanço et al. 2010), mainly of Lepidopteran caterpillars (Richter 2000; Prezoto et al. 2006). Polistes dominulus (Christ) (Eigenbrode et al. 2000); Protonectarina sylveirae (de Saussure), Brachygastra lecheguana (Latreille), Polistes carnifex (Fabricius), Polistes melanosomes (de Saussure), Polistes versicolor (Olivier), Polybia ignobilis (Haliday), Polybia scutellaris (White), Protopolybia exigua (de Saussure) (Desneux et al. 2010), Polybia fastidosusculata (de Saussare) Prontonectarina sylveirae (de Saussare) (Moura et al. 2000), Polistes erythrocephalus (Latreille), Polistescanadensis (Linnaeus) and Polybia sericea (Olivier)

${ }^{1}$ Departamento de Entomologia, Universidade Federal de Viçosa, 36570-000 Viçosa, Minas Gerais State, Brazil, ingpachogro@hotmail.com,zanuncio@ufv.br.

${ }^{2}$ Departamento de Biologia Animal, Universidade Federal de Viçosa, 36570-000 Viçosa, Minas Gerais State, Brazil, pricarola@gmail.com, lucasus@hotmail.com

${ }^{3}$ Departamento de Biologia Geral, Universidade Federal de Viçosa, 36570-000 Viçosa, Minas Gerais State, Brazil. jeserrao@ufv.br

*Author for correspondence
\end{abstract}


(Bellotti et al.1992) feed on larvae of forest and agricultural Lepidopteran pests (Zanuncio et al. 1993; Leite et al. 2001). The study of these insects is important in food webs because they can feed on herbivores (Gonring et al. 2003, Weiss et al. 2004).

Insect defoliators of banana plants include Calligo illioneus (Cramer) (Lepidoptera: Nymphalidae), Antichloris eriphia (Fabricius) (Lepidoptera: Arctiidae) and Opogona sacchari (Bojer) (Lepidoptera: Lyonetiidae), which may decrease fruit production (Watanabe 2007).

Wasps were collected in the campus of the Federal University of Viçosa $\left(20^{\circ} 45^{\prime} \mathrm{S} 42^{\circ} 52^{\prime} \mathrm{W}\right)$ in Viçosa, Minas Gerais State, Brazil on plants of banana (Musa spp.) with entomological nets (Souza \& Prezoto 2006). These insects were killed in ether vapor and preserved in $70 \%$ ethanol for identification.

Three colonies of Polybia platycephala and one of $P$. versicolor were found at $3.50 \mathrm{~m}$ high under leaves of banana plants, which are long and wide, providing protection against adverse environmental conditions.

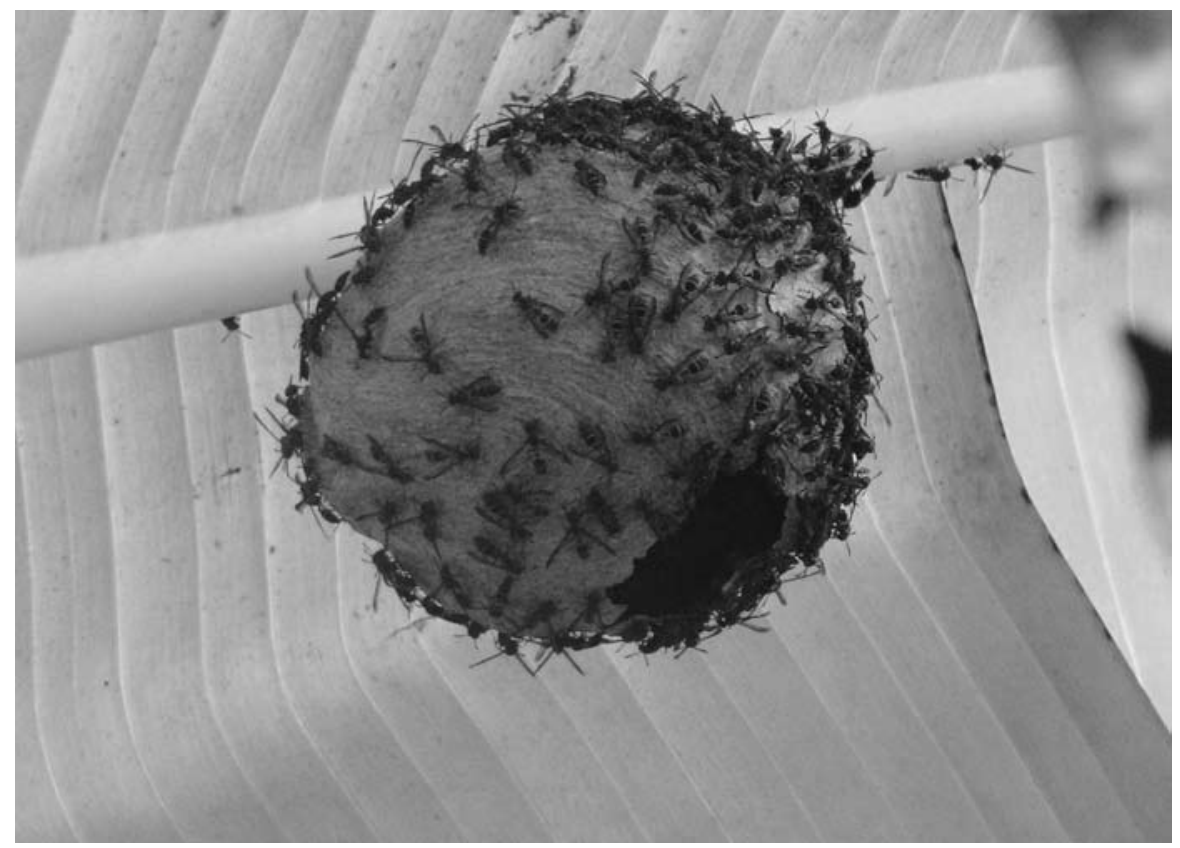

Fig. 1. Nest of the social wasp Polybia platycephala (Hymenoptera: Vespidae) on a Musa spp. (banana) plant. 
The occurrence of $P$. platycephala enlarges the geographic distribution of this wasp, which was reported in the Brazilian States of Amazonas, Goiás, Mato Grosso, Minas Gerais, São Paulo and Rio de Janeiro and also in Peru and Suriname. Its nests have many horizontal combs built under leaves of perennial plants (Richards 1978, Lima \& Prezoto 2003, Prezoto et al. 2005). The social wasp $P$. platycephala preys on different insects including Spodoptera frugiperda (J.E. Smith) (Lepidoptera: Noctuidae), Mocis latipes (Guennée) (Lepidoptera: Noctuidae), Alabama argilacea (Hübner) (Lepidoptera:Noctuidae), Sciarasp.(Diptera) and Psilla sp.(Heteroptera) playing an important role as biological control agent of insect pests in the field and urban environments (Prezoto et al. 2005).

Colonies of $P$. versicolor were reported on different substrates such as leaves, rocks, roots and abandoned nests of other wasps (De Oliveira et al. 2010). Polistes versicolor occurs from Amazonas to Rio Grande do Sul States in Brazil and its nests are formed by a single comb attached to the substrate by a peduncle (Richards 1978, Prezoto et al. 2006). This wasp has been reported preying on larvae of the following Lepidopterans: Hedylepta indicata (Fabricius),Elasmopalpus lignosellus (Zeller) (Pyralidae), Spodoptera frugiperda (JE Smith), Heliothis virescens (Fabricius), Pseudoplusia includens (Walker) (Noctuidae), Chlosyne lacinia saundersii (Doubleday \& Hewitson) (Nymphalidae) and Automeris sp. (Saturniidae). Management of P. versicolor colonies in artificial shelters may be an effective strategy of pest control (Prezoto et al. 2006).

The presence of P. platycephala (Fig. 1) on banana plants should be monitored, because this wasp may spread bacterial disease of banana and heliconia caused by Ralstonia solanacearum (Smith) Yabuuchi et al. race 2, reported in Belize, Brazil, Colombia, Costa Rica, Ecuador, El Salvador, Grenada, Guatemala, Guyana, Honduras, Jamaica, Mexico, Nicaragua, Panama, Peru, Suriname, Trinidad and Tobago, USA, Venezuela (America), Ethiopia, Libya, Malawi, Nigeria, Senegal (Africa), India, Philippines, Indonesia, Malaysia, Thailand and Vietnam (Asia) (Zoccoli et al. 2009). Ralstonia solanacearum may infect plants by contact with infected tools, root-root contact, soil-root contact (Zoccoli et al. 2009) or by flower visiting insects such as stingless bees Trigona spp., wasps Polybia spp. and fruit flies Drosophila spp. (Buddenhagen \& Kelman 1964). 
Wasp nests on plants of Musa spp. can be dangerous to workers in this culture, mainly during banana harvesting. This is the first record of the social wasps $P$. platycephala and $P$. versicolor nesting on banana plants, suggesting that further studies should be focused on prey preference of these wasps in banana plantations to determine if these species can be used in programs of integrated pest management, mainly of defoliating caterpillars.

\section{ACKNOWLEDGEMENTS}

The authors thank "Conselho Nacional de Desenvolvimento Científico e Tecnológico (CNPq)", Coordenação de Aperfeiçoamento de Pessoal de Nível Superior (CAPES)" and "Fundação de Amparo a Pesquisa do Estado de Minas Gerais (FAPEMIG)”.

\section{REFERENCES}

Buddenhagen, I. \& A. Kelman 1964. Biological and physiological aspects of Bacterial Wilt caused by Pseudomonas solanacearum. Annual Review of Phytopathology 2(1): 203230.

Bellotti, A.C., V.B. Arias \& O.L. Guzman 1992. Biological control of the cassava hornworm Erinnyis ello (Lepidoptera: Sphingidae). Florida Entomologist 75(4): 506-515.

Desneux N., E. Wajnberg, K. Wyckhuys, G. Burgio, S. Arpaia, C. Narváez-Vasquez, J. González-Cabrera, D. Catalán-Ruescas, E. Tabone, J. Frandon, J. Pizzol, C. Poncet, T. Cabello \& A. Urbaneja 2010. Biological invasion of European tomato crops by Tuta absoluta: ecology, geographic expansion and prospects for biological control. Journal of Pest Science 83(3): 197-215.

De Oliveira S.A., M.M. de Castro \& F. Prezoto 2010. Foundation pattern, productivity and colony success of the paper wasp, Polistes versicolor. Journal of Insect Science 10: 1-10.

Eigenbrode, S.D., L. Rayor, J. Chow \& P. Latty 2000. Effects of wax bloom variation in Brassica oleracea on foraging by a vespid wasp. Entomologia Experimentalis et Applicata 97 (2): 161-166.

Gonring, R.A.H., M.C. Picanço, J.C. Zanuncio, M. Puiatti \& A.A. Semeão 2003. Natural biological control and key mortality factors of the pickleworm, Diaphania nitidalis Stoll (Lepidoptera: Pyralidae), in cucumber. Biological Agriculture and Horticulture 20 (4): 365-380.

Leite, G.L.D., M. Picanço, R.N.C. Guedes \& J.C. Zanuncio 2001. Role of plant age in the resistance of Lycopersicon hirsutum f. glabratum to the tomato leafminer Tuta absoluta (Lepidoptera: Gelechiidae). Scientia Horticulturae 89(2): 103-113.

Lima, M.A.P.\&F. Prezoto 2003. Foraging activity rhythm in the Neotropical swarm-founding wasp Polybiaplatycephalasylvestris Richards, 1978 (Hymenoptera, Vespidae) in different seasons of the year. Sociobiology 42 (3): 754-752. 
Moura, F., M. Picanço, A.H.R. Gonring \& C.H. Bruckner 2000. Seletividade de inseticidas a três Vespidae predadores de Dione juno juno (Lepidoptera: Heliconidae). Pesquisa Agropecuária Brasileira 35(2): 251-257.

Picanço, M.C., I.R. Oliveira, J.F. Rosado, F.M. Silva, P. C. Gontijo \& R.S. Silva 2010. Natural biological control of Ascia monuste by the social wasp Polybia ignobilis (Hymenoptera: Vespidae). Sociobiology 56 (1): 67-76.

Prezoto, F. \& N. Gobbi 2005. Flight range extension in Polistes simillimus Zikán, 1951 (Hymenoptera, Vespidae). Brazilian Archives of Biology and Technology 48 (6): 947-950.

Prezoto, F., M.A.P. Lima \& V.L.L. Machado 2005. Survey of preys captured and used by Polybia platycephala (Richards) (Hymenoptera: Vespidae, Epiponini). Neotropical Entomology 34 (5): 849-851.

Prezoto, F., H.H. Santos-Prezoto, V.L.L. Machado \& J.C. Zanuncio 2006. Prey captured and used in Polistes versicolor (Olivier) (Hymenoptera: Vespidae) nourishment. Neotropical Entomology 35 (5): 707-709.

Richards, O.W. 1978. The social wasps of the Americas. British Museum of Natural History. London, $580 \mathrm{pp}$.

Richter, M.R2000.Social wasp (Hymenoptera: Vespidae) foragingbehavior. Annual Review of Entomology 45(1): 121-150.

Souza, M.M. \& F. Prezoto 2006. Diversity of social wasps (Hymenoptera, Vespidae) in semideciduous forest and Cerrado (Savanna) regions in Brazil. Sociobiology 47 (1): 135-147.

Souza, M.M., J.E. Serrão \& J.C. Zanuncio 2010. Social wasps (Hymenoptera: Vespidae) as indicators of conservation degree of riparian forests in Southeast Brazil. Sociobiology 56(2): 387-396.

Watanabe, M.A 2007. Pragas da bananeira atacando Heliconia latispatha Benth. (Heliconiaceae). Neotropical Entomology 36 (2): 312-313.

Weiss, M.R., E.E.Wilson \& I. Castellanos 2004. Predatory wasps learn to overcome the shelter defense of their larval prey. Animal Behaviour 68 (1): 45-54.

Zanuncio, J.C., J.B. Alves, G.P. Santos \& W.O. Campos 1993. Levantamento e flutuação populacional de lepidópteros associados à eucaliptocultura: VI-Região de Belo Oriente, Mina Gerais. Pesquisa Agropecuária Brasileira 28 (10): 1121-1127.

Zoccoli, M.D., K.C. Tomita \& H.C. Uesugil 2009. Ocorrência de murcha bacteriana em helicônias e musácea ornamental no Distrito Federal. Tropical Plant Pathology 34 (1): 045-046.

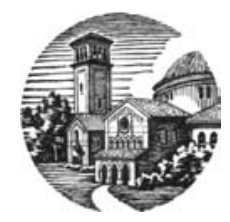


